\title{
Rhizosphere pH dynamics in trace-metal-contaminated soils, monitored with planar $\mathrm{pH}$ optodes
}

\author{
Stephan Blossfeld • Jérôme Perriguey • \\ Thibault Sterckeman • Jean-Louis Morel • \\ Rainer Lösch
}

Received: 8 June 2009 / Accepted: 1 October 2009/Published online: 17 October 2009

(C) Springer Science + Business Media B.V. 2009

\begin{abstract}
The present study presents new insights into $\mathrm{pH}$ dynamics in the rhizosphere of alpine pennycress (Noccaea caerulescens (J. Presl \& C. Presl) F.K. Mey), maize (Zea mays L.) and ryegrass (Lolium perenne L.), when growing on three soils contaminated by trace metals with initial $\mathrm{pH}$ values varying from 5.6 to 7.4 . The $\mathrm{pH}$ dynamics were recorded, using a recently developed $2 \mathrm{D}$ imaging technique based on planar $\mathrm{pH}$ optodes. This showed that alpine pennycress and ryegrass alkalinized their rhizosphere by up to 1.7 and $1.5 \mathrm{pH}$ units, respectively,
\end{abstract}

Responsible Editor: Philippe Hinsinger.

\footnotetext{
S. Blossfeld · J. Perriguey $\cdot$ T. Sterckeman $(\bowtie) \cdot$

J.-L. Morel

Nancy Université, INRA,

Laboratoire Sols et Environnement,

2, avenue de la Forêt de Haye, BP 172,

54505 Vandoeuvre-lès-Nancy cedex, France

e-mail: Thibault.Sterckeman@ensaia.inpl-nancy.fr

R. Lösch

Nebensteingasse 1,

63739 Aschaffenburg, Germany

Present Address:

S. Blossfeld

Forschungszentrum Juelich, ICG-3, Phytosphere,

Juelich, Germany

Present Address:

J. Perriguey

INRA, Centre de Nancy, SDAR,

54280 Champenoux, France
}

whereas maize acidified its rhizosphere by up to $-0.7 \mathrm{pH}$ units. The alkalinization by the roots of alpine pennycress and ryegrass was permanent and not restricted to specific root zones, whereas the acidification along the maize roots was restricted to the elongation zone and thus only temporary. Calculations showed that such $\mathrm{pH}$ changes should have noticeable effects on the solubility of the trace metal in the rhizosphere, and therefore on their uptake by the plants. As a result, it is suggested that models for trace metal uptake should include precise knowledge of rhizospheric $\mathrm{pH}$ conditions.

Keywords Maize $\cdot$ Alpine pennycress $\cdot$ Ryegrass · Cadmium $\cdot$ Alkalinization $\cdot$ Acidification

\section{Introduction}

The $\mathrm{pH}$ value of soils is known to be a heterogeneously distributed parameter (Fischer et al. 1989; Hinsinger et al. 2005; Jaillard et al. 1996). This variability can be caused by several abiotic physico-chemical reactions in the soils, e.g. the dissolution of $\mathrm{CO}_{2}$, the reduction of iron or manganese hydroxides or the hydrolysis of $\mathrm{Al}$ in the soil pore water (Hinsinger et al. 2003; Kirk 2004; Scheffer and Schachtschabel 2002). Besides abiotic reactions, biotic activities can also influence the soil $\mathrm{pH}$ values. For example plant roots actively alter the rhizospheric $\mathrm{pH}$, to extents varying with those of the diffusion processes (Kim and Silk 1999). This 
can happen for instance due to proton $\left(\mathrm{H}^{+}\right)$excretion, uptake or hydroxide $\left(\mathrm{OH}^{-}\right)$excretion at the root surface, which is known to happen during either ammonium or nitrate uptake by roots (Marschner 1995; Marschner and Römheld 1983). It has also been shown that plant roots change the rhizospheric availability of nutrients like $\mathrm{Fe}$ and $\mathrm{P}$ by altering the pH value (Kirk and Bajita 1995; Kirk and Kronzucker 2005; Marschner 1995; Walter et al. 2000).

On the other hand, $\mathrm{pH}$ is a factor which can significantly affect the speciation and the solubility of trace metals in soils (Bruemmer et al. 1986; Sauvé et al. 2000) and therefore their availability to plants. As a consequence, the change in the rhizospheric $\mathrm{pH}$ might influence the living conditions and the composition of plants growing in soils contaminated with elements such as $\mathrm{Cd}, \mathrm{Ni}, \mathrm{Pb}$ or $\mathrm{Zn}$. An increase in trace metal availability, due to a root mediated $\mathrm{pH}$ shift towards acidic conditions, leads to an increased availability of those trace metals for plant uptake (Christensen 1984; Scheffer and Schachtschabel 2002). This increased availability can cause severe injury and even death to trace-metal sensitive species or at least enhance the concentration of potentially toxic elements in edible plant organs. On the other hand, an increase in soil $\mathrm{pH}$ around the roots, by reducing the availability of toxic trace elements would be a way to reduce the exposure of plants to potentially toxic trace metals (Bravin et al. 2009a, b). While some studies have suggested that there is no correlation between rhizospheric $\mathrm{pH}$ value and the uptake of trace metals (Luo et al. 2000; McGrath et al. 1997), other works have described positive correlations between the trace metal concentration in the plants and the rhizospheric $\mathrm{pH}$ value (Loosemore et al. 2004; Monsant et al. 2008). However, none of these studies investigated $\mathrm{pH}$ changes at the mm-scale resolution along the root surfaces, but used mixtures of several grams of soil samples, which might have diluted the possible effect of root induced $\mathrm{pH}$ changes. Recently, a rhizosphere $\mathrm{pH}$ gradient at the millimeter scale was assessed, using glass electrodes to measure the $\mathrm{pH}$ in the solution extracted from thin slices of an acidic soil, previously in contact with a root mat (Bravin et al. 2009b). Nevertheless, a quantification of the rhizosphere $\mathrm{pH}$ of soil-grown single roots or root systems with high spatial and temporal resolution was still lacking.

Therefore, to quantify the dynamics of $\mathrm{pH}$ at the rhizosphere scale of soil roots grown in trace-metal- contaminated soils, a newly developed method for the non-invasive $2 \mathrm{D}$ imaging of $\mathrm{pH}$, based on planar $\mathrm{pH}$ optodes (Blossfeld and Gansert 2007) was used and adapted to this specific question. The results of this approach applied to three plant species grown in three unsaturated soils contaminated with $\mathrm{Cd}, \mathrm{Pb}$ and $\mathrm{Zn}$ are presented in this article.

\section{Material and methods}

Soils

Three soils were used (soils A, B \& C). Soils A and soil $\mathrm{B}$ were strongly contaminated with $\mathrm{Cd}, \mathrm{Pb}$ and $\mathrm{Zn}$ by the atmospheric emissions of two lead and zinc smelters (Sterckeman et al. 2002). They were characterized in a previous study (Sterckeman et al. 2005) as a sandy-clayey-loamy soil with a $\mathrm{pH}\left(\mathrm{H}_{2} \mathrm{O}\right)$ of 6.2 and as a silty-loamy-sandy soil with a $\mathrm{pH}\left(\mathrm{H}_{2} \mathrm{O}\right)$ of 8.1 , respectively (Table 1). Besides their different $\mathrm{pH}$ values, the soils differ in the bioavailability of trace metals as can be seen from the $E$ values for $\mathrm{Cd}$ and $\mathrm{Zn}$, which are much higher in soil A than in soils B and C (Sterckeman et al. 2005). Soil C was chosen because it was loamy and showed a similar $\mathrm{pH}\left(\mathrm{H}_{2} \mathrm{O}\right)$ to soil A but no (or very low) contamination with $\mathrm{Pb}$ and $\mathrm{Zn}$. Indeed, this soil enabled the measurement of $\mathrm{pH}$ in the rhizosphere of ryegrass on a slightly acid soil, as in pot cultivation this plant only rarely grew on soil A, possibly because of the toxicity of a highly available $\mathrm{Zn}$ content. The soils were sieved at $2 \mathrm{~mm}$ before being placed into the rhizoboxes. The $\mathrm{pH}$ $\left(\mathrm{CaCl}_{2}\right)$ of each soil was measured according to ISO 10390:2005. Fertilizers were not added to the soils as the major nutrient status showed no deficiencies (Table 1).

Plant species and cultivation

Three species with contrasting abilities to accumulate trace metals were investigated. One of the selected species was alpine pennycress (Noccaea caerulescens (J. Presl \& C. Presl) F.K. Mey also known as Thlaspi caerulescens J. \& C. PRESL., Viviez population), which is a well-known $\mathrm{Cd}$ and $\mathrm{Zn}$ hyperaccumulator (Reeves et al. 2001). The second species chosen, ryegrass (Lolium perenne L., cv Prana), can be specified as a trace metal "excluder" as the metal is 
Table 1 Characteristics of the soils used during the experimentation. Data compiled from Sterckeman et al. (2004), Sterckeman et al. (2005) and Gérard (2000) except $\mathrm{pH} \mathrm{CaCl}$, for which our own measurements were carried out according to ISO 10390:2005. $E$ values were measured through the isotope dilution technique and represent the pool of labile elements, i.e. the ions in solution together with the sorbed ones in equilibrium with those in solution

\begin{tabular}{|c|c|c|c|c|}
\hline & & Soil A & Soil B & Soil C \\
\hline \multirow[t]{3}{*}{ Particle size distribution $\mathrm{g} \mathrm{kg}^{-1}$} & Clay & 208 & 162 & 204 \\
\hline & Silt & 469 & 602 & 454 \\
\hline & Sand & 323 & 236 & 342 \\
\hline $\mathrm{pH}\left(\mathrm{H}_{2} \mathrm{O}\right)$ & & 6.2 & 8.1 & 6.3 \\
\hline $\mathrm{pH}\left(\mathrm{CaCl}_{2}\right)$ & & 5.7 & 7.4 & 5.9 \\
\hline $\mathrm{CaCO}_{3} \mathrm{~g} \mathrm{~kg}^{-1}$ & & 0 & 13 & $<1$ \\
\hline Organic $\mathrm{C} \mathrm{g} \mathrm{kg}{ }^{-1}$ & & 26.38 & 16.9 & 15.7 \\
\hline $\mathrm{P}$ Olsen $\mathrm{g} \mathrm{P}_{2} \mathrm{O}_{5} \mathrm{~kg}^{-1}$ & & 0.021 & 0.156 & 0.025 \\
\hline $\mathrm{C} / \mathrm{N}$ ratio & & 16.8 & 12.9 & 8.9 \\
\hline $\mathrm{CEC} \mathrm{cmol}+\mathrm{kg}^{-1}$ & & 11.8 & 12.0 & 11.0 \\
\hline \multirow[t]{3}{*}{ Exchangeable cations $\mathrm{cmol}+\mathrm{kg}^{-1}$} & $\mathrm{Ca}^{2+}$ & 7.1 & 12.6 & 9.0 \\
\hline & $\mathrm{Mg}^{2+}$ & 1.2 & 0.4 & 3.5 \\
\hline & $\mathrm{K}^{+}$ & 0.6 & 0.5 & 0.3 \\
\hline Total $\mathrm{Cd} \mathrm{mg} \mathrm{kg}^{-1}$ & & 19.9 & 19.5 & 6.32 \\
\hline Total $\mathrm{Zn} \mathrm{mg} \mathrm{kg}{ }^{-1}$ & & 3,362 & 1,538 & 52 \\
\hline$E_{\mathrm{Cd}} \mathrm{mg} \mathrm{kg}^{-1}$ & & 14.7 & 6.7 & 4.2 \\
\hline$E_{\mathrm{Zn}} \mathrm{mg} \mathrm{kg}^{-1}$ & & 1,654 & 145 & ND \\
\hline
\end{tabular}

During cultivation, the rhizoboxes were placed on

generally less concentrated in its shoots than in the soil (Sterckeman et al. 2005). Previous work showed that it was able to grow on soil A, although this was potentially phytotoxic as a consequence of the high availability of trace metals. Maize (Zea mays L. cv INRA MB862) was also investigated, due to the fact that this species is a standard model plant, for which some data on rhizospheric $\mathrm{pH}$ are available (Fan and Neumann 2004; Peters 2004; Taylor and Bloom 1998). This species can accumulate the metal in its shoots, although it is known to be sensitive to trace metals (Page et al. 1981) and shows higher concentrations in roots than in shoots (Perriguey et al. 2008).

The selected plant species were transplanted to or sown in PVC rhizoboxes (height $300 \mathrm{~mm}$, width $150 \mathrm{~mm}$, depth $50 \mathrm{~mm}$ ) that were filled with one of the three soil types described above. The front plates of the rhizoboxes were cut from conventional glass of $2 \mathrm{~mm}$ in thickness and fixed to the rhizobox by use of six removable metal clamps (Fig. 1). Alpine pennycress was first sown on compost and grown there for 10 to 14 days before transplantation. Maize was germinated on moistened filter paper for two to 3 days before transplantation while ryegrass was directly sown onto the soil in the rhizoboxes. Three seedlings of maize and alpine pennycress where transplanted in each rhizobox, while rye grass seedlings were thinned after germination to about 10 plants per rhizobox. a rack with an inclination of $45^{\circ}$ to force the roots to grow along the front plates. By this arrangement, the roots were also protected from light. The plants were grown and investigated in a growth chamber with a $16 \mathrm{~h} / 8 \mathrm{~h}$ day-night cycle $\left(350 \mu \mathrm{mol}\right.$ photons $\mathrm{m}^{-2} \mathrm{~s}^{-1}$

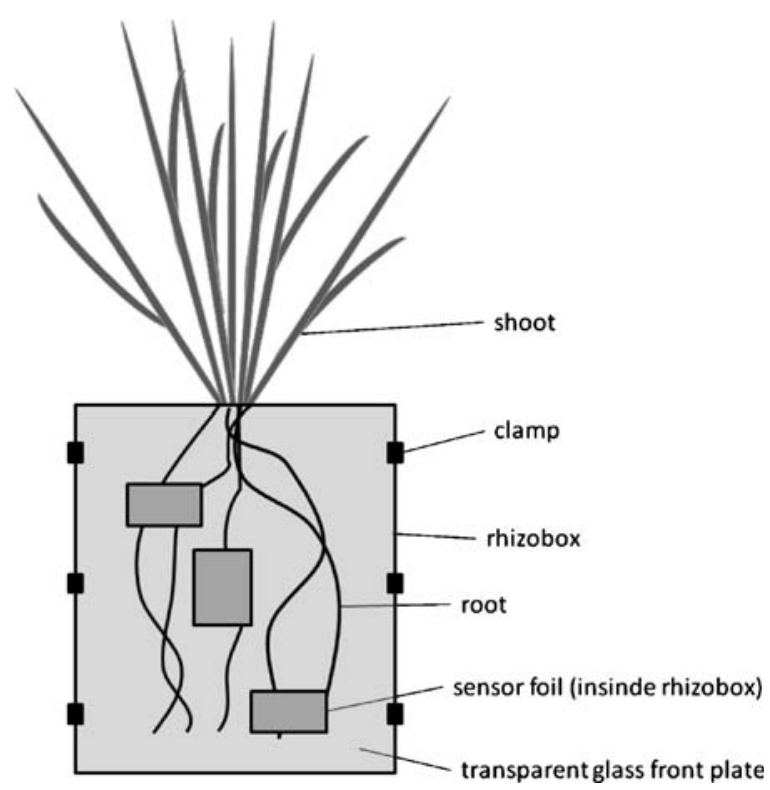

Fig. 1 Design of the rhizoboxes used: Clamps hold a glass front plate, planar $\mathrm{pH}$ optode sensor foils are placed inside, in direct contact with the roots and the glass front plate 
during daytime). Average day and night temperature were $24^{\circ} \mathrm{C}$ and $18^{\circ} \mathrm{C}$, respectively. From the outset, the water content of each rhizobox was set to $70 \%$ to $80 \%$ of the water holding capacity, controlled by weighing, and was kept constantly at this level during the experiments. The duration of the cultivation of the three species in the rhizoboxes prior to the measurements was different due to the species specific root growth; i.e. 6-8 weeks for alpine pennycress, 8-9 days for maize and 4-5 weeks for ryegrass.

$\mathrm{pH}$ measurement

The $\mathrm{pH}$ measurements were made using a non-invasive optical technique, described by Blossfeld and Gansert (2007). This technique uses planar $\mathrm{pH}$ optodes, based on the measurement of the fluorescence decay time of $\mathrm{pH}$ sensitive indicator dyes (Gansert and Blossfeld 2008; Gansert et al. 2006; Huber et al. 2001; Klimant et al. 2001). These indicator dyes are dispersed and immobilized on an inert supporting film, creating a thin sensor foil of $10 \mu \mathrm{m}$ in thickness. The measurement itself was carried out via an optical glass fiber from outside the rhizobox, which was connected to a light source and measuring device ( $\mathrm{pH}-1$ mini, PreSens $\mathrm{GmbH}$, Regensburg, Germany). The glass fiber was moved automatically by a $\mathrm{x}$-y stepper motor device, connected to and operated by a conventional personal computer. By this, the $\mathrm{pH}$ value could be measured in a line scanning mode from outside the rhizobox. This decoupling of sensor and detector, allows a non-invasive investigation of the $\mathrm{pH}$ dynamics in the soil-rhizosphere-root network, using light as the carrier of information (Blossfeld and Gansert 2007, Fig. 2).

According to the root growth and the position of individual roots and root networks during the cultivation, the glass front plate was removed and one to three planar $\mathrm{pH}$ optodes (PreSens $\mathrm{GmbH}$; maximal dimensions: $20 \mathrm{~mm} \times 40 \mathrm{~mm}$ ) were fixed to the inner surface of the front plate using a thin layer of silicon grease as adhesive. Afterwards, the front plate was fixed to the rhizobox again, to ensure that the roots and the soil were in direct contact with the planar $\mathrm{pH}$ optodes (i.e. sensor foils in Figs. 1 \& 2).

The initial objective was to measure the soil $\mathrm{pH}$ (i) at the tip of a single root, (ii) on a single root as far as possible from its apex and (iii) in densely rooted zone. This was possible in the case of ryegrass and alpine

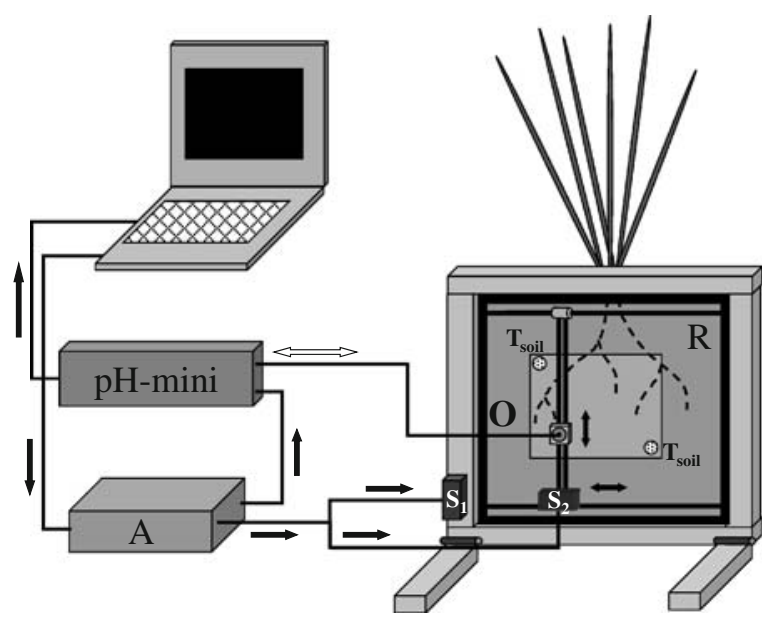

Fig. 2 Diagram of the hardware components used for the optical non-invasive $\mathrm{pH}$ measurements. The planar optode $(\mathrm{F})$ is scanned from outside via an optical fiber $(\mathrm{O})$, which is moved by two stepper motors $\left(\mathrm{S}_{1}, \mathrm{~S}_{2}\right)$. A specific interface controls the stepper motors and triggers the fiber-optic detection device (pH-mini). The data transfer to the computer (C) and the trigger impulses are indicated as black arrows. The optical data transfer is indicated by a double-headed white arrow. The soil temperature is measured at two positions $\left(\mathrm{T}_{\text {soil }}\right)$ in the rhizobox (R). Reproduced from Blossfeld and Gansert (2007) with kind permission from Plant, Cell \& Environment (Wiley-Blackwell)

pennycress. However, maize roots did not form a root network until the main roots reached the bottom of the rhizoboxes. As this could have altered the whole root system's functioning, measurement of $\mathrm{pH}$ in a densely rooted zone was not carried out for this species. Alternatively, the tips of the main roots and aged parts of these main roots were investigated.

Depending on the position and the number of roots in contact with the sensor foils, variable sections of these foils were scanned by the fiber in 2 to $3 \mathrm{~mm}$ steps and $4 \mathrm{~s}$ intervals. The $\mathrm{pH}$ value was mapped using SigmaPlot software (Systat Software, Inc., San Jose, CA, USA). The resulting 2D color contour plots represented the measured $\mathrm{pH}$ value of the selected sections of the planar optodes. For further technical details, calibration procedure and data processing, see Blossfeld and Gansert (2007).

In the case of ryegrass grown on soil $\mathrm{B}$, the measurement was carried out on three rhizoboxes. As there was no significant difference between the three rhizoboxes (data not shown), the measurements for the other plant species were carried out in only one rhizobox for each of the three soils. 


\section{Results}

$\mathrm{pH}$ measurements

In Fig. 3, the dynamics of the rhizospheric $\mathrm{pH}$ of ryegrass, growing in soil $\mathrm{B}$, is exemplarily shown. During the course of 1 week (D1-D7) five roots grew across the investigated section of the planar $\mathrm{pH}$ sensor foil. All five roots were indicated by red dots on the photograph in the lower right image in Fig. 3. This photograph was taken at the end of the experiment, i.e. 6 days after D7, when the front plate of the rhizobox was removed, showing other visible roots in this image that were grown after D7. The alkalinization of two roots (indicated with roman numerals I, II) was detectable at the end of the light cycle of day one of the experiment (indicated as D1 at 19:00). Twenty four hours later (D2 at 19:00) root II had already grown across the entire surface of the investigated section (i.e. more than $20 \mathrm{~mm}$ ) and root I had grown about $9 \mathrm{~mm}$ during the same time. During the next $24 \mathrm{~h}$ (D3 at 19:00), a third root appeared (indicated as III) and the alkalinization of the roots I and II was greater than the previous days (up to $0.4 \mathrm{pH}$ units). The rhizosphere $\mathrm{pH}$ of root I was more alkaline (up to $\mathrm{pH} 8.4$ ) than the rhizosphere of root II or root III (both up to $\mathrm{pH} 8.0$ ). Until day seven of the experiment (D7 at 11:00), all three roots grew out of, and a fourth and a fifth root started to grow across, the investigated section of the sensor foil. The 2D-imaging technique also revealed that the radius of proximate alkalinization around single roots could reach up to three millimeters of the root surface. The maximum alkalinization by the ryegrass roots compared to the non-rooted bulk soil (soil B) was $1.2 \mathrm{pH}$ units, as the $\mathrm{pH}$ of bulk soil was 7.2.

In the dense root networks, the soil $\mathrm{pH}$ map was highly complex and formed a mosaic like pattern. Figure 4 illustrates such a pattern for a root network of ryegrass growing in soil $\mathrm{B}$. In this case, due to the root activity even the $\mathrm{pH}$ of non-rooted zones is alkalinized; only a few spots with the initial $\mathrm{pH}$ value were left compared to the situation shown in Fig. 3.

The values given in Table 2 represent the average of the measured $\mathrm{pH}$ values from ten sampling points from the root surfaces and the bulk soil of the last measurement of each experiment (when the root tip of the single root fully crossed the sensor foil). They show that all investigated plant species affect the rhizospheric $\mathrm{pH}$ in all investigated soil types.
As shown above, ryegrass roots alkalinized their rhizosphere in soil $\mathrm{B}$, as they also did when growing in soil C (Table 2). However, in soil $\mathrm{C}$ the rhizospheric $\mathrm{pH}$ value was not affected by single roots of ryegrass, whereas an alkalinization within root networks increased the rhizospheric $\mathrm{pH}$ to $\mathrm{pH} 7.7$ (Table 2). Due to an increased root curvature and thus a reduced contact between sensor foil and roots, the number of sampling points was reduced in the case of single root investigations in soil $\mathrm{C}$.

For the roots of alpine pennycress, a clear alkalinization of the rhizosphere was also found (Fig. 5). In soil A, the roots of alpine pennycress alkalinized their rhizosphere up to an average $\mathrm{pH}$ of 7.0 within root networks (Table 2). This corresponds to an alkalinization of $1.4 \mathrm{pH}$ units compared to the average $\mathrm{pH}$ of the bulk soil $(\mathrm{pH}=5.6)$. For soil $\mathrm{B}$, a rhizosphere alkalinization by the roots of alpine pennycress of up to a maximum of $1.2 \mathrm{pH}$ units along single roots was detectable (Table 2). In soil $\mathrm{C}$ the fully-grown individuals of alpine pennycress did not form a dense root network, due to reduced root growth of the individuals, but again a rhizosphere alkalinization compared to the bulk soil was clearly detectable along the single roots (up to $1.7 \mathrm{pH}$ units; Table 2).

Contrarily to ryegrass and alpine pennycress, young maize roots did not alkalinize, but acidified the rhizosphere (Table 2; Fig. 6). Compared to the $\mathrm{pH}$ of the bulk soil, the rhizosphere of maize showed a $\mathrm{pH}$ value by up to $-0.7 \mathrm{pH}$ units in the case of soil $\mathrm{A}$, corresponding to a rhizospheric $\mathrm{pH}$ value of $\mathrm{pH} 4.9$ (average $\mathrm{pH}$ bulk soil: 5.6 ). In the case of soil $\mathrm{B}$, the rhizospheric acidification was in a lower range $(-0.3 \mathrm{pH}$ units). In soil C, only a small amount of data points were available, due to an increased root curvature and a consequently reduced contact between sensor foil and roots. Within this soil, the results show no significant $\mathrm{pH}$ change in the rhizosphere of young single roots (Table 2).

The investigation of aged parts of the maize roots showed contrasting effects of the roots on rhizospheric $\mathrm{pH}$ values, within a quantitative change of -0.1 (soil A), +0.1 (soil B) to $+0.3 \mathrm{pH}$ units (soil C). This indicates that a stronger acidification is locally restricted to the root tip and the elongation zone of the roots (Table 2). Furthermore, when growing in soil B and especially in soil C, an alkalinization along the basal parts of the single maize roots could be observed. 

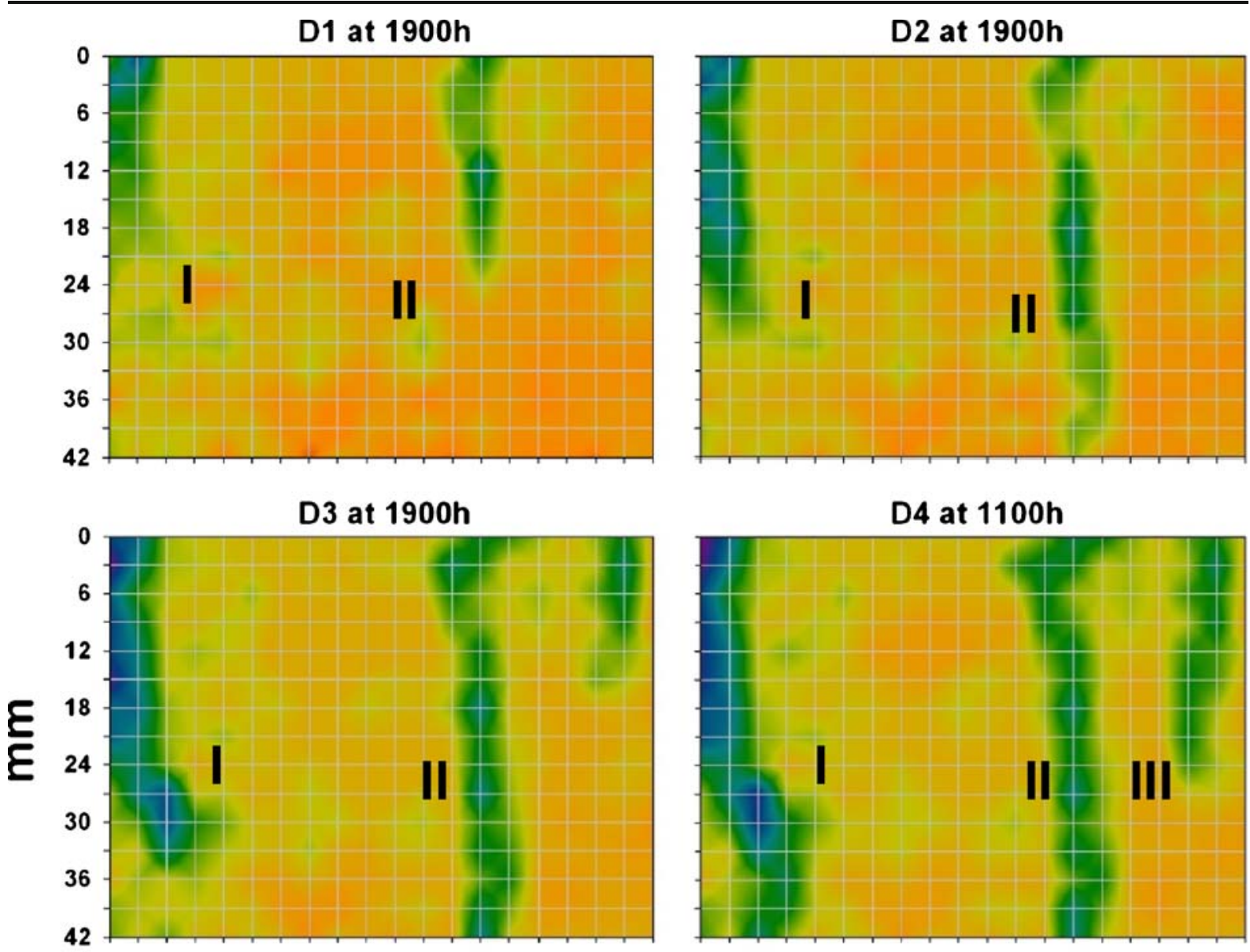

\section{D4 at $1100 h$}
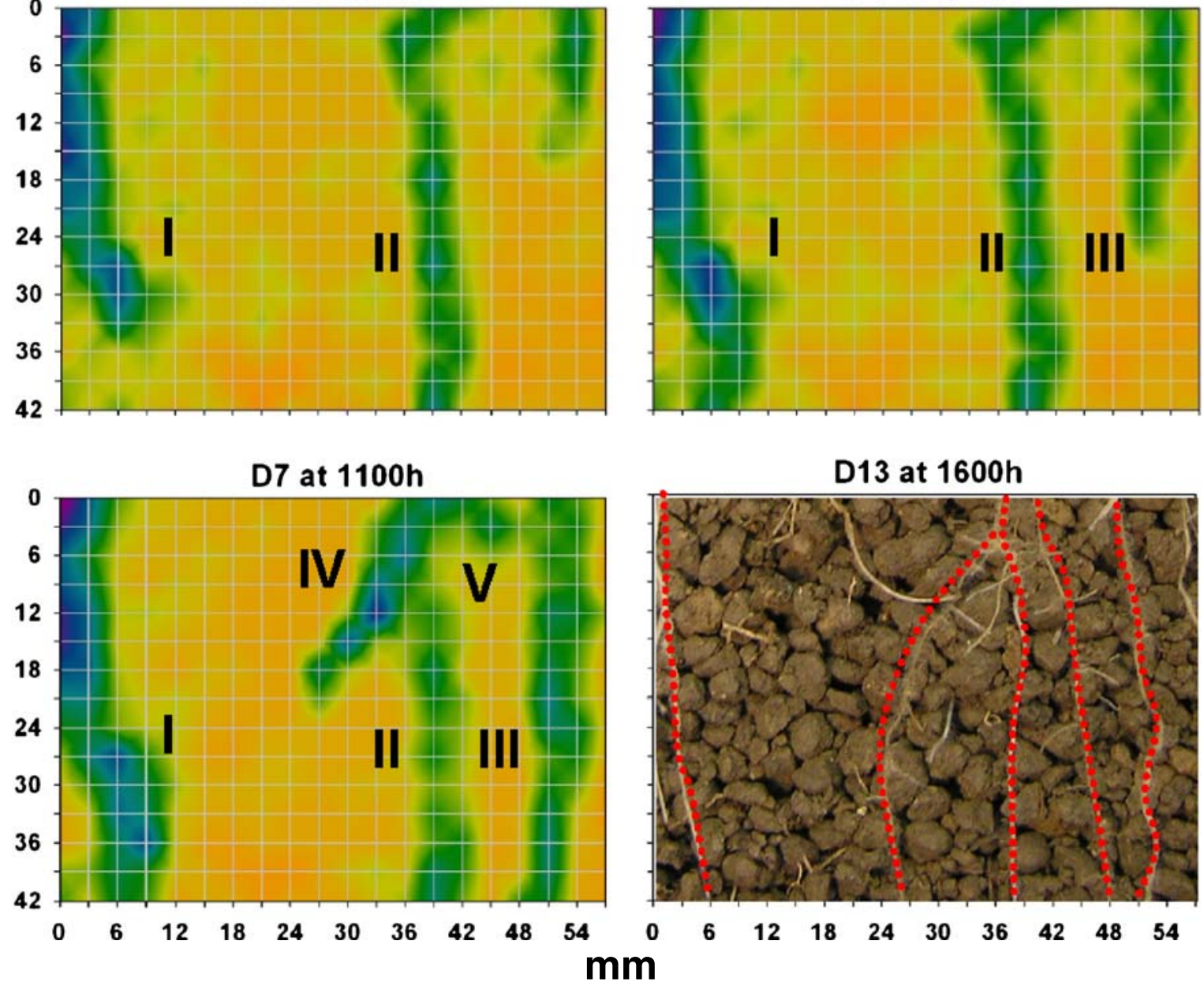

Fig. 3 Series of 2D images of the $\mathrm{pH}$ pattern in the rhizosphere of young ryegrass roots growing in soil B. Roman numerals indicate different roots, abscissa and ordinate in $\mathrm{mm}$ scale. The

photograph was taken at the end of the experiment. Red dotted lines in the photograph indicate location of the indexed roots (I-V) 
Fig. 4 Series of 2D images of the $\mathrm{pH}$ pattern in the rhizosphere of a network of ryegrass roots growing in soil B. The photograph was taken at the end of the experiment. Red dotted lines in the photograph indicate location of main roots
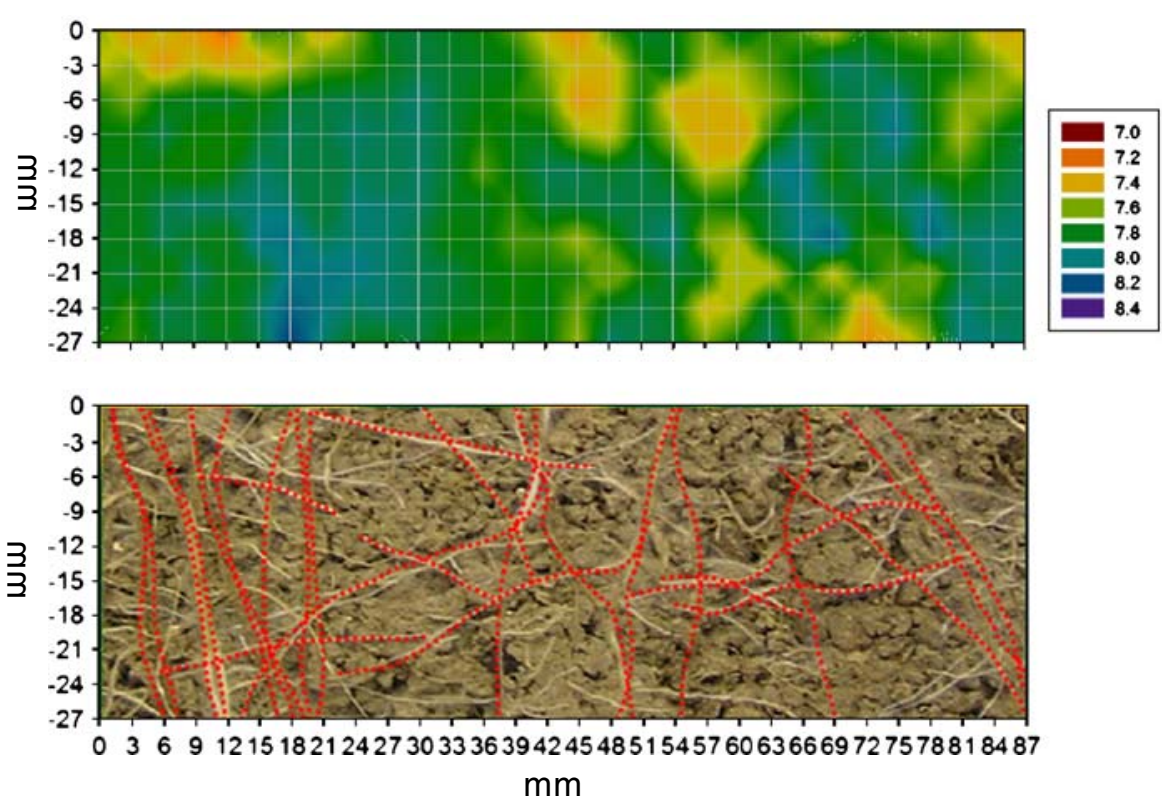

Finally, it can be noticed that the $\mathrm{pH}$ of the bulk soil measured by the planar optodes was similar to that measured in $\mathrm{CaCl}_{2} 0.01 \mathrm{M}$ soil suspension and generally lower than that measured in the water suspension (Tables $1 \& 2$ ).

\section{Discussion}

Planar optodes allow a continuous and cartographic monitoring of soil or rhizosphere $\mathrm{pH}$, at a millimetric scale. This technique was initially validated for the measurement of the rhizosphere $\mathrm{pH}$ of a plant species (Juncus effusus L.) that grows in water-saturated soils (Blossfeld and Gansert 2007). Proving the suitability of this technique under even moderate soil moisture conditions had still to be done (Hinsinger et al. 2009; Luster et al. 2009). Our study confirms the use of planar $\mathrm{pH}$ optodes for a wide range of rhizospheric research, from moderate to waterlogged soil moisture conditions. Moreover, our measurements with this technique revealed remarkable results with regard to contrasting rhizospheric $\mathrm{pH}$ dynamics of three plant species.

The species investigated show different influences of their roots on rhizospheric $\mathrm{pH}$ patterns. The roots of ryegrass and alpine pennycress alkalinize the rhizosphere, whereas the roots of maize acidify it. The acidification along the roots of maize found in our study conforms to previous findings (Fan and Neumann 2004; Peters 2004; Taylor and Bloom 1998). The observed restriction of the acidification

Table 2 Rhizospheric and bulk soil $\mathrm{pH}$ measured non-invasively with planar $\mathrm{pH}$ optodes

\begin{tabular}{|c|c|c|c|c|c|c|c|c|c|}
\hline \multirow[b]{2}{*}{ Soil type } & \multicolumn{3}{|c|}{ Ryegrass } & \multicolumn{3}{|c|}{ Alpine pennycress } & \multicolumn{3}{|l|}{ Maize } \\
\hline & A & $\mathrm{B}$ & $\mathrm{C}$ & A & B & $\mathrm{C}$ & A & $\mathrm{B}$ & $\mathrm{C}$ \\
\hline $\begin{array}{l}\text { Average } \mathrm{pH} \text { along } \\
\text { single root }\end{array}$ & - & $7.8 \pm 0.1 * * *$ & $6.5 \pm 0.3 *(n=4)$ & $6.8 \pm 0.1 * * *$ & $8.4 \pm 0.2 * * *$ & $7.8 \pm 0.3 * * *$ & $4.9 \pm 0.2 * * *$ & $\begin{array}{l}7.1 \pm 0.2 * * * \\
(n=9)\end{array}$ & $\begin{array}{l}6.0 \pm 0.1 \text { n.s. } \\
(n=4)\end{array}$ \\
\hline $\begin{array}{l}\text { Average } \mathrm{pH} \text { in root } \\
\text { network/ along aged roots }\end{array}$ & - & $7.9 \pm 0.1 * * *$ & $7.7 \pm 0.2 * * *$ & $7.0 \pm 0.2 * * *$ & $7.9 \pm 0.3^{* * *}$ & n.d. & $5.5 \pm 0.1 * * *$ & $7.5 \pm 0.1 * * *$ & $6.5 \pm 0.2^{*}$ \\
\hline pH bulk soil & - & $7.4 \pm<0.1$ & $6.2 \pm 0.3$ & $5.6 \pm 0.1$ & $7.5 \pm 0.1$ & $6.1 \pm 0.1$ & $5.6 \pm<0.1$ & $7.4 \pm 0.1$ & $6.2 \pm 0.3$ \\
\hline
\end{tabular}

Asterisks indicate significant differences between rhizospheric and bulk soil $\mathrm{pH}$ of the selected species and soil type $t$-test, $n=10$ unless stated differently

${ }^{*} p<0.05 * * p<0.01 * * * p<0.001$ 
Fig. 5 2D image of a typical rhizospheric $\mathrm{pH}$ pattern of young alpine pennycress roots growing in soil B. The photograph was taken at the end of the experiment. Color codes for $\mathrm{pH}$-values differ from those used in Figs. 3 and 4

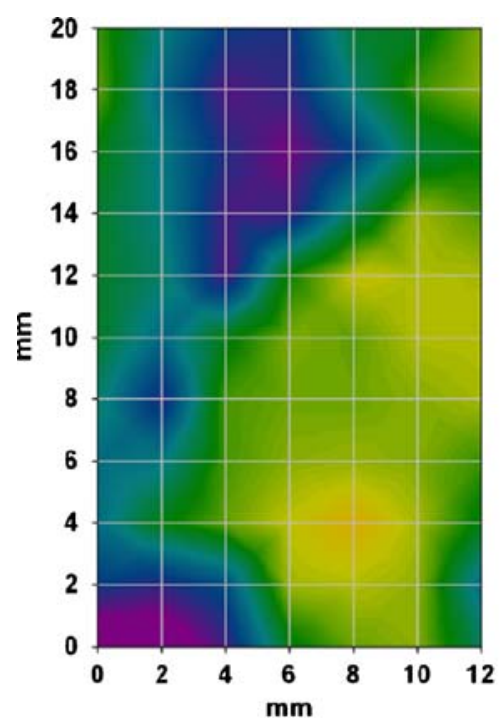

zone to the root tip and the elongation zone was also reported by others (Fan and Neumann 2004; Peters 2004). This acidification might be caused by a locally restricted uptake of positively charged ions, such as potassium or ammonium, that are necessary for plant nutrition. This effect is well-known to cause an acidification along the roots (Bravin et al. 2009a; Marschner 1995; Miller and Cramer 2004). However, as reported earlier (Colmer and Bloom 1998; Taylor and Bloom 1998), the uptake of ammonium does not seem to be limited to a specific zone along the root surface of maize.

On the other hand, several studies clearly related the locally restricted acidification along the roots of maize to the acid-growth mechanism (Peters 2004; Pilet et al. 1983; Versel and Mayor 1985; Versel and Pilet 1986). These studies linked a local acidification 2-4 $\mathrm{mm}$ behind the root apex of maize roots to the
Fig. 6 2D image of a typical rhizospheric $\mathrm{pH}$ pattern of young maize roots growing in soil A. The photograph was taken at the end of the experiment. Color codes for $\mathrm{pH}$-values differ from those used in Figs. 3 and 4

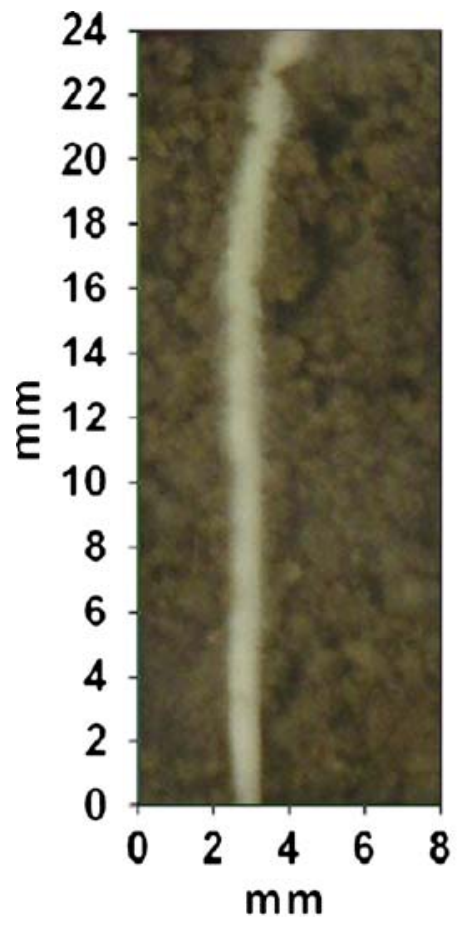


Table 3 Calculated $\mathrm{Cd}$ concentration and partitioning coefficient of cadmium $\left(K_{d}{ }^{C d}\right)$ in the rhizosphere compared to bulk soil conditions. Data are based on the $\mathrm{pH}$ data from Table 2, previously described cadmium concentrations in the bulk soil (Gérard 2000; Perriguey 2006) and the Eqs. (1) and (2)

\begin{tabular}{|c|c|c|c|c|c|c|c|c|c|c|c|c|}
\hline \multirow[b]{3}{*}{ Soil type } & \multicolumn{9}{|c|}{ Rhizospheric soil } & \multicolumn{3}{|c|}{ Bulk soil } \\
\hline & \multicolumn{3}{|c|}{ Ryegrass } & \multicolumn{3}{|c|}{ Alpine pennycress } & \multicolumn{3}{|l|}{ Maize } & & & \\
\hline & A & $\mathrm{B}$ & $\mathrm{C}$ & A & $\mathrm{B}$ & $\mathrm{C}$ & A & $\mathrm{B}$ & $\mathrm{C}$ & A & $\mathrm{B}$ & $\mathrm{C}$ \\
\hline $\mathrm{Cd}\left(\mathrm{nmol} \mathrm{L}{ }^{-1}\right)$ & - & 33.4 & 475 & 69.5 & 8.4 & 6.0 & 5,524 & 167 & 1,502 & 1,102 & 78 & 1,015 \\
\hline$K_{d}^{C d}\left(\mathrm{~L} \mathrm{~kg}^{-1}\right)$ & - & 1,667 & 385 & 540 & 3,281 & 1,667 & 63 & 757 & 219 & 139 & 1,098 & 265 \\
\hline [Cd] bulk soil/[Cd] rhizosphere & - & 2 & 2.1 & 16 & 9 & 171 & 0.20 & 0.47 & 0.68 & & & \\
\hline$K_{d}^{C d}$ bulk soil/ $K_{d}^{C d}$ rhizosphere & - & 0.7 & 0.7 & 0.26 & 0.33 & 0.16 & 2.21 & 1.45 & 1.21 & & & \\
\hline
\end{tabular}

highest level of root growth of this particular region. Since the other processes mentioned above do not explain the locally restricted acidification in our case, the acid-growth mechanism might apply to our experiments as well. However, this has to be clarified through further investigation.

In contrast, the rhizosphere alkalinization by the roots of ryegrass and alpine pennycress is obviously permanent and the entire root surface of these species modifies the rhizospheric $\mathrm{pH}$ value towards alkaline conditions. For ryegrass, other studies have also reported an alkalinization in the rhizosphere (see for instance Gahoonia et al. 1992; Pinel et al. 2003), through the measurement of the $\mathrm{pH}$ of a soil suspension at the end of the experiments. To our knowledge there are no other data available in the literature about the $\mathrm{pH}$ pattern in the rhizosphere of alpine pennycress.

The underlying process of this alkalinization by these two species is yet unknown and has to be identified by further investigations. One possible explanation might be the uptake of negatively charged ions necessary for plant nutrition like nitrate $\left(\mathrm{NO}_{3}{ }^{-}\right)$(Bravin et al. 2009a; Marschner 1995; McClure et al. 1990; Miller and Cramer 2004; Rausch and Bucher 2002; Taylor and Bloom 1998), i.e. the reversed process as discussed above concerning the acidification of maize rhizosphere. This would lead to the assumption that ryegrass and alpine pennycress show a preference towards for instance $\mathrm{NO}_{3}^{-}$, while maize would preferentially absorb $\mathrm{NH}_{4}^{+}$.

Moreover, plants have been found to have a developmental program for the control of shoot metal concentrations, causing a seasonally-varying pattern of phytoaccumulation over a large range of metal availabilities in the soil (Silk et al. 2006). The resulting variation in trace metal root uptake could also cause rhizosphere $\mathrm{pH}$ variations. On the other hand, it is also possible that microbial activities associated to the plant roots are responsible for these different rhizospheric $\mathrm{pH}$ patterns. Depending on the plant species, different microbial communities might have been established (Costa et al. 2006; Wieland et al. 2001) and therefore affected rhizospheric $\mathrm{pH}$ due to specific proton generating-reactions e.g. nitrification or iron oxidation. However, the microbial activities were neither controlled nor quantified during our study in order to verify this assumption. Since no data are yet present to verify these assumptions, further studies of the ion fluxes and role of microbial communities along the root surfaces of ryegrass and alpine pennycress are needed.

Furthermore, small-scaled rhizospheric $\mathrm{pH}$ changes as demonstrated above are generally not taken into account in mechanistic models that simulate the uptake of trace metals by roots (Barber 1995; Roose and Kirk 2009; Sterckeman et al. 2004; Tinker and Nye 2000). However, the concentration of the solute in the soil solution $\left(C_{l}\right)$, which is a key parameter in the soil-to-plant transfer (Sterckeman et al. 2004) is highly dependent on the pH (Bruemmer et al. 1986; Sauvé et al. 2000). In some recent works, rhizosphere $\mathrm{pH}$ gradients were successfully modeled (Bravin et al. 2009b; Loosemore et al. 2004). This approach could be coupled to a reactive transport model describing trace element root uptake, as previously done for phosphorus by Kirk and Saleque (1995). The use of the optode technology presented here would then help to parameterize or validate such a model.

In our study, measured alkalinization along the roots of ryegrass and alpine pennycress above $\mathrm{pH} 7$ 
(up to $\mathrm{pH} 8.6$ ) should strongly decrease the availability of trace-metals in the soil solution due to an increase of the sorption capacity of the soil (Bravin et al. 2009a; Christensen 1984; Loosemore et al. 2004; Ma and Lindsay 1995; Sauvé et al. 2000; Scheffer and Schachtschabel 2002). It is well-known that the logarithm of the amount of soluble metals like $\mathrm{Cd}^{2+}$ linearly decreases as $\mathrm{pH}$ increases. Depending on the specific soil conditions, slopes of this relationship can vary between -0.6 and $-2.0 \log$ units (Ma and Lindsay 1995; Salam and Helmke 1998). In $\mathrm{NaNO}_{3}$ extracts of 120 French cultivated soil samples, Sterckeman et al. (2000) found a mean slope of -1 , which gave a correlation between $\mathrm{pH}$ and $\mathrm{Cd}$ as follows:

$\log \left(\mathrm{Cd} \mathrm{NaNO}_{3}\right)=b-1.0 \mathrm{pH}$,

$b$ being a constant depending on the soil.

$\mathrm{NaNO}_{3}$ extracts can be regarded as a reliable method for assessing the metal concentrations in soil solutions (Gupta and Aten 1993; Lebourg et al. 1998). Therefore, this relationship might serve to estimate and highlight the effect of the recorded $\mathrm{pH}$ changes in the rhizosphere of the three selected plants on the solubility of $\mathrm{Cd}$.

The Cd concentration in the bulk soil is $1,102 \mathrm{nmol} \mathrm{L}^{-1}$ and $78.3 \mathrm{nmol} \mathrm{L}^{-1}$ for soils A and B (Gérard 2000) and $1,015 \mathrm{nmol} \mathrm{L}^{-1}$ for soil C (Perriguey 2006). Using these concentrations and mean bulk pH in Eq. (1), the soil-dependent constant $b$ will be 8.6, 9.3 and 9.2 for the soils $\mathrm{A}, \mathrm{B}$ and $\mathrm{C}$, respectively. Thus, $C_{l}$ in the rhizosphere can be estimated using the average $\mathrm{pH}$ values along a single root (Table 2).

The impact of rhizospheric $\mathrm{pH}$ changes on the availability of $\mathrm{Cd}$ was also assessed using the relationship between $K_{d}{ }^{C d}$ and $\mathrm{pH}$ as described by Sauvé et al. (2000) from 830 data points:

$\log K_{d}{ }^{C d}=0.49 \mathrm{pH}-0.6$,

where $K_{d}{ }^{C d}\left(\mathrm{~L} \mathrm{~kg}^{-1}\right)$ is the partitioning coefficient of $\mathrm{Cd}$, i.e. the ratio between soil total and dissolved metal.

According to these calculations, the recorded alkalinization of the rhizosphere by the roots of ryegrass and alpine pennycress should have decreased the $\mathrm{Cd}$ concentration in the soil solution up to more than two orders of magnitude, compared to the bulk soil conditions (Table 3). On the other hand, the maximal acidification of the rhizosphere by the roots of maize should have strongly increased the concen- tration of Cd. Similarly, the $K_{d}{ }^{C d}$ values should clearly increase in the alkalinized rhizosphere of ryegrass and alpine pennycress compared to those in the bulk soil, reflecting the sorption of the metal on the solid phase with $\mathrm{pH}$ increase (Table 3 ). As expected, $K_{d}{ }^{C d}$ should decrease in the rhizosphere of maize (or at least in the acidified part of it), thanks to the dissolution of part of the metal from the solid phase.

In conclusion, depending on plant species, soil type, and even on the location along the root in the case of maize, the availability of $\mathrm{Cd}$ is clearly different in the rhizosphere than in the bulk soil. As suggested by sensitivity analysis carried out on mechanistic modeling (Sterckeman et al. 2004), such differences should have important consequences on the uptake of Cd by the plants. Finally, the use of planar optodes shows a great potential for the monitoring of $\mathrm{pH}$ dynamics in a variety of soils and in the rhizosphere of various plant species.

Acknowledgements This work was supported by the "Deutscher Akademischer Austausch Dienst" (DAAD) and the "Ministère de l'Education Nationale, de l'Enseignement Supérieur et de la Recherche" within the framework of the PROCOPE programme in 2008.

The authors would like to express their thanks to Bernard Colin (INPL(ENSAIA)/INRA), W. Seidel, A. Lanzinger, M. Laug and W. Müller (University Düsseldorf) for their technical support and PreSens GmbH for the supply of planar optodes.

\section{References}

Barber SA (1995) Soil nutrient bioavailability. A mechanistic approach. Wiley, New York, p 414

Blossfeld S, Gansert D (2007) A novel non-invasive optical method for quantitative visualization of $\mathrm{pH}$ dynamics in the rhizosphere of plants. Plant Cell Environ 30:176-186

Bravin M, Martí A, Clairotte M and Hinsinger P (2009a) Rhizosphere alkalisation - a major driver of copper bioavailability over a broad $\mathrm{pH}$ range in an acidic, coppercontaminated soil. Plant Soil 318:257-268

Bravin M, Tentscher P, Rose J, Hinsinger P (2009b) Rhizosphere $\mathrm{pH}$ gradient controls copper availability in a strongly acidic soil. Environmental Science \& Technology (in press)

Bruemmer GW, Gerth J, Herms U (1986) Heavy metal species, mobility and availability in soils. Z PflanzenernaÉhr Bodenkd 149:382-398

Christensen TH (1984) Cadmium soil sorption at low concentrations: II. Reversibility, effect of changes in solute composition, and effect of soil aging. Water, Air, \& Soil Pollution 21:115-125

Colmer TD, Bloom AJ (1998) A comparison of NH4+ and NO3- net fluxes along roots of rice and maize. Plant Cell Environ 21:240-246 
Costa R, Götz M, Mrotzek N, Lottmann J, Berg G, Smalla K (2006) Effects of site and plant species on rhizosphere community structure as revealed by molecular analysis of microbial guilds. FEMS Microbiol Ecol 56:236-249

Fan L, Neumann PM (2004) The spatially variable inhibition by water deficit of maize root growth correlates with altered profiles of proton flux and cell wall $\mathrm{pH}$. Plant Physiol 135:2291-2300

Fischer WR, Flessa H, Schaller G (1989) pH values and redox potentials in microsites of the rhizosphere. Z PflanzenernaÉhr Bodenkd 152:191-195

Gahoonia T, Claassen N, Jungk A (1992) Mobilization of phosphate in different soils by ryegrass supplied with ammonium or nitrate. Plant Soil 140:241-248

Gansert D, Blossfeld S (2008) The application of novel optical sensors (Optodes) in experimental plant ecology. In Progress in Botany. pp 333-358

Gansert D, Stangelmayr A, Krause C, Borisov AY, Wolfbeis OS, Arnold A, Müller A (2006) Hybrid optodes (HYBOP). In: Popp J, Strehle M (eds) Biophotonics: Visions for a better health care. Wiley $\mathrm{VCH}$, Weinheim, pp $477-518$

Gérard E (2000) Caractérisation du cadmium phytodisponible des sols par des méthodes isotopiques. In Ecole Nationale Supérieure d'Agronomie et des Industries Alimentaires. Institut National Polytechnique de Lorraine, VandoeuvreLès-Nancy, p 153

Gupta SK, Aten C (1993) Comparison and evaluation of extraction media and their suitability in a simple model to predict the biological relevance of heavy metal concentrations in contaminated soils. Int J Environ Anal Chem 51:25-46

Hinsinger P, Plassard C, Tang C, Jaillard B (2003) Origins of root-mediated $\mathrm{pH}$ changes in the rhizosphere and their responses to environmental constraints: a review. Plant Soil 248:43-59

Hinsinger P, Gobran GR, Gregory PJ, Wenzel WW (2005) Rhizosphere geometry and heterogeneity arising from root-mediated physical and chemical processes. New Phytol 168:293-303

Hinsinger P, Bengough A, Vetterlein D, Young I (2009) Rhizosphere: biophysics, biogeochemistry and ecological relevance. Plant and Soil

Huber C, Klimant I, Krause C, Wolfbeis OS (2001) Dual lifetime referencing as applied to a chloride optical sensor. Anal Chem 73:2097-2103

Jaillard B, Ruiz L, Arvieu J-C (1996) pH mapping in transparent gel using color indicator videodensitometry. Plant Soil 183:85-95

Kim TK, Silk WK (1999) A mathematical model for $\mathrm{pH}$ patterns in the rhizospheres of growth zones. Plant Cell Environ 22:1527-1538

Kirk GJD (2004) The biogeochemistry of submerged soils. In The Biogeochemistry of Submerged Soils. pp i-xi

Kirk GJD, Bajita JB (1995) Root-induced iron oxidation, pH changes and zinc solubilization in the rhizosphere of lowland rice. New Phytol 131:129-137

Kirk GJD, Kronzucker HJ (2005) The potential for nitrification and nitrate uptake in the rhizosphere of wetland plants: a modelling study. Ann Bot 96:639-646

Kirk GJD, Saleque MA (1995) Solubilization of phosphate by rice plants growing in reduced soil: prediction of the amount solubilized and the resultant increase in uptake. Eur J Soil Sci 46:247-255

Klimant I, Huber C, Liebsch G, Neurauter G, Stangelmayr A, Wolfbeis OS (2001) Dual lifetime referencing (DLR) - a new scheme for converting fluorescence intensity into a frequencydomain or time-domain information. In: Valeur B, Brochon JC (eds) New trends in fluorescence spectroscopy: Application to chemical and life sciences. Springer, Berlin, pp 257-275

Lebourg A, Sterckeman T, Ciesielski H, Proix N (1998) Trace metal speciation in three unbuffered salt solutions used to assess their bioavailability in soil. J Environ Quality 27:584-590

Loosemore N, Straczek A, Hinsinger P, Jaillard B (2004) Zinc mobilisation from a contaminated soil by three genotypes of tobacco as affected by soil and rhizosphere $\mathrm{pH}$. Plant Soil 260:19-32

Luo YM, Christie P, Baker AJ (2000) Soil solution Zn and pH dynamics in non-rhizosphere soil and in the rhizosphere of Thlaspi caerulescens grown in a $\mathrm{Zn} / \mathrm{Cd}$-contaminated soil. Chemosphere 41:161-164

Luster J, Göttlein A, Sarret G, Nowack B (2009) Sampling, defining, characterising and modeling the rhizospherethe soil science toolbox. Plant and Soil

Ma QY, Lindsay WL (1995) Estimation of Cd2+ and Ni2+ activities in soils by chelation. Geoderma 68:123-133

Marschner H (1995) Mineral nutrition of higher plants. Academic, London, p 889

Marschner H, Römheld V (1983) In vivo measurement of root induced $\mathrm{pH}$ changes at the soil-root interface: effect of plant species and nitrogen source. Z Pflanzenphysiol 111:241-251

McClure PR, Kochian LV, Spanswick RM, Shaff JE (1990) Evidence for Cotransport of Nitrate and Protons in Maize Roots: II. Measurement of $\mathrm{NO}(3)$ and H Fluxes with IonSelective Microelectrodes. Plant Physiol 93:290-294

McGrath SP, Shen ZG, Zhao FJ (1997) Heavy metal uptake and chemical changes in the rhizosphere of Thlaspi caerulescens and Thlaspi ochroleucum grown in contaminated soils. Plant Soil 188:153-159

Miller A, Cramer M (2004) Root nitrogen acquisition and assimilation. Plant Soil 274:1-36

Monsant AC, Tang C, Baker AJ (2008) The effect of nitrogen form on rhizosphere soil $\mathrm{pH}$ and zinc phytoextraction by Thlaspi caerulescens. Chemosphere 73:635-642

Page AL, Bingham FT, Chang AC (1981) Cadmium. In: Lepp NW (ed) Effect of heavy metal pollution on plants. Volume 1. Effects of trace metals on plant function. Applied Science, London, pp 77-109

Perriguey J (2006) Evaluation de l'equation de Nye-TinkerBarber pour la modelisation du prelevement de Cadmium par le mais et le tabouret calaminaire. In ENSAIA. INPL, Nancy

Perriguey J, Sterckeman T, Morel J-L (2008) Effect of rhizosphere and plant-related factors on the cadmium uptake by maize (Zea mays L.). Environ Exper Bot 63:333-341

Peters WS (2004) Growth rate gradients and extracellular $\mathrm{pH}$ in roots: how to control an explosion. New Phytol 162:571-574

Pilet P-E, Versel J-M, Mayor G (1983) Growth distribution and surface $\mathrm{pH}$ patterns along maize roots. Planta 158:398 402 
Pinel F, Leclerc-Cessac E, Staunton S (2003) Relative contributions of soil chemistry, plant physiology and rhizosphere induced changes in speciation on $\mathrm{Ni}$ accumulation in plant shoots. Plant Soil 255:619-629

Rausch C, Bucher M (2002) Molecular mechanisms of phosphate transport in plants. Planta 216:23-37

Reeves RD, Schwartz C, Morel JL, Edmondson J (2001) Distribution and metal-accumulating behavior of Thlaspi caerulescens and associated metallophytes in France. Int J Phytoremediat 3:145-172

Roose T, Kirk G (2009) The solution of convection-diffusion equations for solute transport to plant roots. Plant Soil 316:257-264

Salam AK, Helmke PA (1998) The pH dependence of free ionic activities and total dissolved concentrations of copper and cadmium in soil solution. Geoderma 83:281-291

Sauvé S, Hendershot W, Allen HE (2000) Solid-solution partitioning of metals in contaminated soils: dependence on $\mathrm{pH}$, total metal burden, and organic matter. Environ Sci Technol 34:1125-1131

Scheffer F, Schachtschabel P (2002) Lehrbuch der Bodenkunde. Heidelberg, Spektrum

Silk WK, Bambic DG, O’Dell RE, Green PG (2006) Seasonal and spatial patterns of metals at a restored copper mine site II. Copper in riparian soils and Bromus carinatus shoots. Environ Pollut 144:783-789

Sterckeman T, Baize D, Mench M, Sappin-Didier V, Proix N, Gomez A (2000) Comparison de trois methods d'extraction chimique d'estimation de la phytodisponibilité de $\mathrm{Cd}, \mathrm{Cu}, \mathrm{Pb}$ et $\mathrm{Zn}$ pour le blé. In A.I.P. AGREDE-QUASAR program p. 50. Institut National de la Recherche Agronomique (INRA)

Sterckeman T, Douay F, Proix N, Fourrier H, Perdrix E (2002) Assessment of the contamination of cultivated soils by eighteen trace elements around smelters in the North of France. Water Air Soil Pollut 135:173-194

Sterckeman T, Perriguey J, Caël M, Schwartz C, Morel JL (2004) Applying a mechanistic model to cadmium uptake by Zea mays and Thlaspi caerulescens: consequences for the assessment of the soil quantity and capacity factors. Plant Soil 262:289-302

Sterckeman T, Duquene L, Perriguey J, Morel JL (2005) Quantifying the effect of rhizosphere processes on the availability of soil cadmium and zinc. Plant Soil 276:335-345

Taylor AR, Bloom AJ (1998) Ammonium, nitrate, and proton fluxes along the maize root. Plant Cell Environ 21:1255-1263

Tinker PB, Nye PH (2000) Solute movement in the rhizosphere. Oxford University Press, Oxford, p 444

Versel J-M, Mayor G (1985) Gradients in maize roots: local elongation and $\mathrm{pH}$. Planta 164:96-100

Versel J-M, Pilet P-E (1986) Distribution of growth and proton efflux in gravireactive roots of maize (Zea mays L.). Planta 167:26-29

Walter A, Silk WK, Schurr U (2000) Effect of soil pH on growth and cation deposition in the root tip of zea mays L. J Plant Growth Regul 19:65-76

Wieland G, Neumann R, Backhaus H (2001) Variation of microbial communities in soil, rhizosphere, and rhizoplane in response to crop species, soil type, and crop development. Appl Environ Microbiol 67:5849-5854 